Summer 2009

\title{
A Look at Traditional Islam's General Discord with a Permanent System of Global Cooperation
}

\author{
Meghan E. Tepas \\ Indiana University Maurer School of Law
}

Follow this and additional works at: https://www.repository.law.indiana.edu/ijgls

Part of the International Law Commons, and the Religion Law Commons

\section{Recommended Citation}

Tepas, Meghan E. (2009) "A Look at Traditional Islam's General Discord with a Permanent System of Global Cooperation," Indiana Journal of Global Legal Studies: Vol. 16 : Iss. 2 , Article 13.

Available at: https://www.repository.law.indiana.edu/ijgls/vol16/iss2/13

This Note is brought to you for free and open access by the Law School Journals at Digital Repository @ Maurer Law. It has been accepted for inclusion in Indiana Journal of Global Legal Studies by an authorized editor of Digital Repository @ Maurer Law. For more information, please contact rvaughan@indiana.edu.

\section{$\Psi$}

JEROME HALL LAW LIBRARY

INDIANA UNIVERSITY

Maurer School of Law
Blooming ton 


\title{
A Look at Traditional Islam's General Discord with a Permanent System of Global Cooperation
}

\author{
Meghan E. Tepas*
}

\begin{abstract}
In today's world, nation-states do not operate in -isolation. Rather, the myriad global organizations and cross-border treaties evidence that the post-World War II political climate is one of interconnectedness and cooperation between states. Against this backdrop, this Note surveys the tension between the current global world order and a strict adherence to traditional source-based application of Islamic law, Sharia. The tension begins with the concept of statehood, seemingly absent in traditional Islam, and continues with the Islamic unification of religion and state and its limited role for a political leader. Using Iran as an example, this Note argues that political reality has interfered with the strict application of Shari'a thus enabling the Islamic state to engage in the global society. It is this inherent tension that, despite claims to the contrary, limits an Islamic state's ability in today's global society to truly return to "traditional Islam."
\end{abstract}

\section{INTRODUCTION}

In 1979, the Iranian Revolution proclaimed to return the nation to a purely Islamic state adhering to Shari' $a,{ }^{1}$ the law of God, derived primarily from the Koran

* Executive Articles Editor, Indiana Journal of Global Legal Studies, J.D., 2009, Indiana University Maurer School of Law - Bloomington; B.A., 2004, University of Michigan-Ann Arbor. I would like to thank my parents, Tom and Debbie Tepas, for their constant support and encouragement; Professor Timothy Waters for all of his help and insight; the Indiana Journal of Global Legal Studies staff for its assistance; and Abra Dilisio, Kate Dunworth, and David Hutchinson for their irreplaceable friendship.

1. Shari'a is defined by the Oxford American Dictionary as the Muslim code of religious law. This definition will be expounded upon at length later in this Note.

Indiana Journal of Global Legal Studies Vol. 16 \#2 (Summer 2009)

CIndiana University Maurer School of Law - Bloomington 
and the traditions of the Prophet. ${ }^{2}$ The success of the revolution has continually been the subject of debate as Islamic scholars and Muslims around the world struggle to reconcile the religion with the modern, global society of the twenty-first century. This Note will use Iran and Shi' ite doctrine to illustrate the inescapable conflict a Muslim state faces in returning to traditional Islam while simultaneously participating in the arena of global politics. Specifically, I will examine the international agreement as a byproduct of globalization and its incompatibility with traditional Islam, due in large part to the denial of statehood imbedded in traditional doctrine and Islam's strict limitations on a government leadership role. Because Islamic countries, such as Iran, have chosen to participate in global politics--represented here by national leaders and international agreements - they have abandoned certain tenets of Islam and will continue to stray from a faithful application of Sharia law.

As discussed in this Note, traditional Islam refers to a system that, according to Islamic legalists, "is capable of offering solutions to all problems not only in [Islamic countries], but throughout the world utilizing interpretations of religious texts as the exclusive model for governance." ${ }^{3}$ Simply put, in an Islamic country, all laws and norms are derived from the "sources of Islam," namely, the Koran and the traditions of the Prophet. I will review these sources to illustrate that there is no traditional authority for international cooperation and thus, the current state of the global world order ${ }^{4}$ mandates perpetual violation of Sharia and precludes a return to traditional Islam. Part I discusses the concept (or lack thereof) of the state in Islamic law; Part II discusses the role of a leader in an Islamic state and his ability to operate in a global arena; Part III discusses the theory of Islamic international law; and Part IV reviews the justifications offered by heads of Muslim states in an attempt to reconcile Shari'a with international commitments. This Note will conclude by arguing that the inevitability of globalization has foreclosed the possibility that Islamic countries will return to a traditional model of the religion.

2. Mehran Tamadonfar, Islam, Law, and Political Culture in Contemporary Iran, 40 J. Scı. Study Religion 205, 209 (2001).

3. Jeffrey Usman, Note, The Evolution of Iranian Islamism from the Revolution Through the Contemporary Reformers, 35 Vand. J. Transnat'l L. 1679, 1682 (2002) (quoting Asghar Schirazi, The Constitution of Iran: Politics and the State in the Islamic Republic 1 (John O'Kane ed., 1998)).

4. By current world order, I am referring to the period following the World Wars-a period that has embraced the arrival of intricate relations between multiple states and the necessity of international organizations, such as the U.N. and the World Trade Organization. See Giuseppe Schiavone, International Organizations: A Dictionary and Directory 5-10 (7th ed. 2008). 


\section{The Islamic Conception of the State}

The idea that states are distinct and separate legal entities is nearly universally recognized. Even in an era of globalization where people and ideas move freely across borders and heads of state are required to comply with international treaties and bend to pressure from international organizations, the concept of the individual state is nonetheless preserved. By a strict interpretation of classical Islamic sources (both Shi'ite and Sunni), however, the individual state is irreconcilable and incompatible with Shari'a. ${ }^{5}$ According to traditional Islamic theory, the world is divided not by borders and territories of the sovereign but by territorial acceptance of Islam. ${ }^{6} \mathrm{~A}$ territory is considered either part of the dar al-Islam, the territory of Islam, or the dar al-harb, the territory of war. ${ }^{7}$ According to the Encyclopedia of Islam, this dichotomy was conceptualized at the time of the Prophet when Mohammad sent word to neighboring, non-Muslim territories that they must choose conversion to Islam or war. ${ }^{8}$ From this prophetic command a theory of Pax Islamica (Islam's global influence and acceptance of its universality) as a traditional objective of Islam can be extrapolated. ${ }^{9}$ Physical territorial limitations and national boundaries were inconsequential; the only meaningful divide was that of religion. In this vein, the only form of globalization that is inherently Islamic occurs from the dispersion of the faith-a theoretical takeover by the dar al-Islam. It is this territorial distinction, a founding principle of Islam, that prevents any concept of the individual state and, by extension, any concept of relations between such "states," a cornerstone of the post-World War global system.

The dar al-Islam consists of the community of believers, the umma, and nonbelievers who have accepted Islamic sovereignty and live under Muslim rule. The dar al-harb thus consists of the world outside the Islamic dominated regions and

5. See generally Abbas Kelidar, The Shii Imami Community and Politics in the Arab East, 19 MiddeE E. STud. 3, 13 (1983) (describing how Islam maintains loyalty to the religion, not to nationality).

6. Majid Khadduri, Shaybanis's Siyar, The Islamic Law of Nations 1, 11 (1966); see also Louis Henkin et al., International Law: Cases and Materials, at xxi (1993).

7. KhadduRI, supra note 6 , at 11 ; see also Henkin, supra note 6 , at xxi.

8. 1 Oxford Encyclopedia of the Modern Islamic World 337 (1995).

9. Majid Khadduri, The Islamic Theory of International Relations and Its Contemporary Relevance 26 (1965); see also David Westbrook, Islamic International Law and Public International Law: Separate Expressions of World Order, 33 VA. J. INT'L L. 819, 860 (1993) (stating that "Islamic international law thus ultimately aspires to global community, aspires to be the vehicle through which Islam becomes the world, through which the babble of humanity becomes the umma").

10. Khadduri, supra note 9, at 26. 
is, by definition, in a constant state of war with Islam." Theoretically, this is consistent with the idea of Pax Islamica. ${ }^{12}$ This state of war is not defined by traditional notions of combat between states, but rather it is a theoretical war between a territory of non-Muslims and the followers of Islam. The traditional law of Islam recognizes "no other nation than its own." 13 The "war" is not characterized in terms of rival heads of states competing for military power but rather by nonrecognition of an enemy "state" and an attempt to engulf territory into an Islamic empire. ${ }^{14}$ This concept is alive in modern day Iran, as illustrated by paragraph 11 of the Iranian Constitution, which expounds the government's obligation to promote the universality of Islam. ${ }^{15}$

The universality theory quickly proved inevitably flawed and excessively rigid. Even at the height of Islam's expansion and regional domination, it was simply a logistical impossibility to deny the existence of non-Islamic states and the reality of distinct states in general. Relations between the dar al-harb and dar alIslam necessitated some semblance of interaction and authority. ${ }^{16}$ Agreements were subsequently negotiated but were thought to be limited in duration, expiring when all territory was incorporated into the dar al-Islam. This stipulation was required in order to preserve the idea of non-recognition of the non-Muslim state ${ }^{17}$ and represents the first instance when traditional Islam had to be reevaluated and certain tenets reinterpreted to dovetail with the circumstances of the global landscape. In accordance with traditional Islamic theory, then, the signatories of international agreements today are required to embrace the finite nature of a treaty with a state that preaches adherence to traditional Islam, such as Iran.

11. Id.

12. Id. at 11 .

13. Majid Khadduri, Islam and the Modern Law of Nations, 50 Aм. J. INT'L L. 358, 358 (1956).

14. See Olivier Roy, The Failure of Political Islam, at viii (2007) (defining original Islam as "the perception of Islam and of Muslim societies as one global, timeless cultural system").

15. In accordance with the sacred verse of the Koran 21:92 " a single brotherhood (of prophets) and I am your Lord and Cherisher: Therefore worship Me (and no other)."). All cites to the Koran refer to English Translation of the Message of the Quran (Syed Vickar Ahamed trans., 2d ed. 2006). Qanuni Assassi Jumhuri'I Isla'mai Iran [The Constitution of the Islamic Republic of Iran] 1358 [1980] art. 11. "All Muslims form a single nation, and the government of the Islamic Republic of Iran has the duty of formulating its general policies with a view toward cultivating the friendship and the unity of all Muslim peoples. It must constantly strive to bring about the political, economic, and cultural unity of the Islamic world."

16. KuRI, supra note 6 , at 60 .

17. Id. at 13. 


\section{A. The Concept of "State" in the Koran}

Islamic legal scholar and U.N. legal advisor Mohammad Talaat Al Ghunaimi has argued that Islamic recognition of states is not the result of circumstances created by outsiders impelling a global, interconnected society, but rather is by express instruction from the Koran. ${ }^{18}$ Citing verses such as, "And if your Lord had so willed, He could have made (all) mankind one People ...," "'9 Ghunaimi concludes that the recognition of statehood is traditionally Islamic. ${ }^{20}$ While this seems to be a logical interpretation of the verse, he does not reconcile this view with the goal of Pax Islamica.

One may argue that while the religion of Islam should break down borders and strive toward global universality, political Islam tolerates and recognizes these divisions. Such a claim would provide a basic justification for entering into international agreements but not without confronting a foundational element of Islam - the categorical unity of religion and state. ${ }^{21}$ Under traditional notions of Islam, what is good for the state is good for the religion; thus, distinguishing divergent purposes for religion and state is contrary to the theoretical unification.

\section{B. Theories and Implications}

The continued existence of the multiple, territorial sovereign and identifiable Islamic countries of today implies that this polemical distinction has not only been reinterpreted but eradicated from modern Islamic legal practice. Unless the heads of the current Islamic nations decide to relinquish power and combine under the rubric of dar al-Islam, we are unlikely to see any reversion to traditional Islam. Rather than following God's will, Islam has been forced to follow the geopolitical path of a global society created by secular nations. Full recognition of the individual state ultimately occurred by necessity but lacks a foundation in sourcebased Islamic law. It should be noted that while the denial of the state appears

18. Mohammad Talaat Al Ghunaimi, Muslim Conception of International Law and the Western Approach 195 (1968).

19. One may read the full text of Koran 11:118 to suggest that, without national borders and state sovereignty, Islam would still struggle to spread the religion throughout the territory. It declares, "And if your Lord had so willed, He could have made (all) mankind one People, but (even then) they will not stop disagreeing[.]".

20. Al Ghunaimi, supra note 18, at 195.

21. See generally Asma Afsaruddin, The "Islamic State": Genealogy, Facts, and Myths, 48 J. Снurch \& ST. 153, 161 (2006) (stating that the Muslim leader should comply with a prior divine mandate). 
largely theoretical, it is of potentially great importance. For instance, if a Muslim cleric actually succeeded in leading a stringent campaign to comply with all traditional notions of Islam, as traditionalists demanded following the fall of the Shah, it is not difficult to imagine how this could be used as a means of subjugating minority Muslims in a non-Muslim state. ${ }^{22}$ Were the denial of statehood maintained in the current geopolitical environment, Muslims would make up a powerless class of people within non-Muslim states. It is not difficult to see why this result is unacceptable to Iran and why Muslims there and around the world largely ignore this fundamental problem. This further illustrates why a return to this type of strict Shari'a is a practical impossibility.

In his study on the secular state, the controversial scholar Charles Tripp speaks to this problem of state recognition in political Islam, stating, "there is the concern that in seeking to play the game of mass politics successfully within the framework of the modern state, [Islam] will succumb to the secularizing logic of democracy, of economic development, and of the territorial state." ${ }^{23}$ The framework of the debate is reduced to participating in international relations or strictly adhering to the Shari'a notion of a non-secular regime. In a state such as Iran that purports to rely strictly on Shari'a, an honest analysis of this debate would result in domestic political suicide. If one equates the election of traditional Shari'a compliance with non-recognition of non-Islamic states, the result is extreme and unworkable isolation. Denying the reality of international cooperation and opting to exist in isolation has unacceptable consequences for any contemporary political leader. The resulting economic hardships on the nation's people and the political irrelevancy of the government would likely lead to chaos, if not a coup. Political leaders do not voluntarily resort to political suicide, and accordingly, we see states like Iran bending the confinements of the Shari'a. "The Iranian state [has become] the first ... Islamist-regime prisoner of the logic of the state." ${ }^{24}$ Only by ignoring this logical dilemma were Khomeini and subsequent Iranian leaders able to participate in global politics. This political reality smacks of secularism and clearly limits any possibility of returning to a more traditional model of Islam.

While a reformed conception of state recognition is accepted in the vast majority of the Muslim world today, whether based on circumstances or based on the

22. Tamadonfar, supra note 2, at 205.

23. Charles Tripp, Islam and the Secular Logic of the State in the Middle East, in IsLa mic FundaMENTAlism 51, 67 (Abdel Salam Sidahmed \& Anounshiravan Ehteshami eds., 1996).

24. Anoushiravan Ehteshami, Islam as a Political Force in International Politics, in IsLAm iN Worlo Polıtics 29, 33 (Nelly Lahoud \& Anthony H. Johns eds., 2005). 
Koran, it is not universal. For example, the Saudi scholar AbdulHamid A. AbuSulayman follows Ayatollah Khomeini's rejection of the state as being an anti-Islamic concept. ${ }^{25}$ AbuSulayman writes of a world order in which the laws of citizenship and immigration no longer exist and states that "Islamic international law would tear down all 'curtains' erected by the nation-states to 'shield' their citizens against counter-claims to the truth, confident that the truth will ultimately prevail." ${ }^{26}$ This statement reflects the traditional Islamic belief that globalization is a concept strictly limited to the spread of the Prophet's religion.

A return to the denial of statehood would have interesting consequences for the international community: presumably, all international agreements would be immediately void in the eyes of Islam or void following expiration of an Islamicimposed time frame. ${ }^{27}$ Simply stated, there can be no agreements between statesfor trade, peace, or cooperation-if there are no recognized states. Admittedly, this is a rigid reading of traditional Islam, but it serves the purpose of illustrating the basic problem that inevitably results when religious doctrine rests its political and religious leadership in the same hands without distinguishing between actions of a political nature and those that are religious, while simultaneously claiming that all political decisions find justification in religious text.

\section{The Role of a Leader in an Islamic State}

As previously discussed, the 1979 Islamic Revolution theoretically returned Iran to strict compliance with the law of Islam, allowing only those sufficiently trained in Islamic law to govern and ensure Sharia compliance. ${ }^{28}$ Encompassed within this definition is the idea that the state is not political in nature but rather is entirely religious in scope. ${ }^{29}$ The law that regulates the Islamic state is not based upon judicial mandate, executive will, or global norms, but rather is infallible divine law. ${ }^{30}$

25. AbdulHamid A. AbuSulayman, The Islamic Theory of International Relations, at xxix (1987).

26. Id.

27. See Christopher Ford, Siyar-ization and its Discontents: International Law and Islam's Constitutional Crises, 30 Tex. INT'L L.J. 499, 521 (1995).

28. Id. at 500 .

29. See generally Imam Khomeini, Islam and Revolution 55 (Hamid Algar trans. 1981) (iterating that Islamic government may therefore be defined as the rule of divine law over men).

30. Id. ("[I]n Islam the legislative power and competence to establish laws belongs exclusively to God Almighty.... No one has the right to legislate and no law may be executed except the law of the Divine Legislator."); see also Qanuni Assassi Jumhuri'I Isla'mai Iran [The Constitution of the Islamic Republic of Iran] 1358 [1980] art. 91 ("[I]n order to examine the compatibility of the legislation passed 
According to Islamic law, all law is divinely inspired and unequivocally precludes legislation by the subordinate. ${ }^{31}$ The nature of Islamic law thus provides, in theory, for a very limited role for the head of state and the government in general: the leader of an Islamic state is a vehicle for transmission of the Shari'a, and he must conduct himself and his government accordingly. In order to legitimately partake in global politics, the head of an Islamic state must distinguish his action from secular legislation. ${ }^{32}$ As the following sections show, this is an insurmountable task, which illustrates the incompatibility of traditional Islam with modern global politics. Before drawing this conclusion, I will review the historical beginnings of Islamic leadership.

It is axiomatic in both traditional and contemporary Islam that Mohammad was both a Messenger of God and the leader of the Muslim community. ${ }^{33}$ This second function serves as the equivalent to the modern day "head of state" and that presents the problem of defining the authority and power of the Prophet's successor. As a messenger of God, Mohammad's actions and sayings were directly attributed to God and thus unquestionably Islamic by definition. It was undisputed that there would not be a successive Prophet upon Mohammad's passing; the revelation was complete. ${ }^{34}$ Who would succeed as the leader of the Muslim community, however, was unresolved and quickly became an issue of extraordinary concern.

Upon his death, those closest to the Prophet recognized that the survival of Islam required that a new leader be selected..$^{35}$ Islam had not assumed a position of religious global dominance, and consequently, required a leader to actuate this goal. Additionally, the Koran makes reference to such a successor through a statement made by God to the Angels: "I will create a vicegerent on earth." ${ }^{36}$ It was clear there was to be a successor, but reaching a consensus through means of tribal selection proved a difficult task - one that led to the first major split within Islam. ${ }^{37}$

by the Islamic Consultative Assembly with Islam, a council to be known as the Guardian Council is to be constituted."); N.J. Coulson, A History of Islamic Law 120 (1964).

31. Cf. Asghar Schirazi, The Constitution of Iran: Politics and the State in the Islamic RePUBLIC 17, 17 (1997) (discussing the Iranian Constitution's base in Shari'a stating that because of its "relation to the divine source of knowledge and its perfection, [it] is endowed with universality and possesses the vitality to solve all humankind's social and political problems in every time and place.").

32. See generally КномеinI, supra note 29 (discussing Islamic constitution government as one not of popular sovereignty but of divine authority over men as established in the Koran).

33. Coulson, supra note 30, at 11.

34. Francis E. Peters, A Reader of Classical Islam 118 (1994); see also Koran 112:1.

35. Peters, supra note 34 , at 117.

36. Koran 2:30.

37. The remainder of the Note will be devoted to Shi'ite doctrine. I chose to focus on this sect primarily because of Iran's high profile position on the world stage and because the task of creating a purely Islamic state has largely been undertaken by the Shi' ite regions. 
According to Shi' ite doctrine, the rightful successor is chosen by designation. Ali, chosen by the Prophet, was the first recognized successor, the First Imam, ${ }^{38}$ thus beginning the concept that leadership authority was devoid of temporal consideration and was not a product of community consensus. ${ }^{39}$

The leadership institution of Shi'ite Islam, the imamate, headed by the Imam, provides a source of law deriving its authority from the text of the Koran. ${ }^{40}$ Because of his position as the designated authority, the Imam is permitted to issue legal decisions and guidance based on the closed revelation of the Koran, but is prohibited from legislating. ${ }^{41}$ This must be so because legislating had effectively ceased with the death of Mohammad, leaving the Imam only to guide, to preserve, and to explain divine law in an authoritative fashion. ${ }^{42}$ The chain of divinely selected Imams continued until the Twelfth Imam disappeared as an infant, effectively halting the system of successive leadership. ${ }^{43}$ It is believed that the Twelfth Imam was hidden by God and would be divinely revealed at a later time. ${ }^{44}$ The period of "Lesser Occultation" arose in which four agents were the spokespersons for the Hidden Imam, thereby filling his authoritative role. ${ }^{45}$ This period was followed by the "Greater Occultation," characterized by a complete lack of communication with the concealed spiritual and political leader of the Muslim community. ${ }^{46}$ The Shi'ites were left to operate within an authoritative vacuum. As a result, Shi' ite Islam was forced to break with the tradition of divinely selected leaders and to eventually resort to what appears to be leadership that operates more for political purposes than religious authority. Such is the case with modern-day Iran.

Shi'ite theory holds that the Twelfth Imam still lives, and thus, there is no legal justification to replace him as political head of the community. ${ }^{47}$ Questions of authority are determined by reference to the "authority verse" of the Koran:

38. Cyril Glasse, The New Encyclopedia of Islam: Concise Encyclopedia of Islam 482 (1988).

39. Peters, supra note 34 , at 122-24.

40. See Koran 29:49, which states, "No! These are the clear and firm Signs that are in the hearts of those gifted with knowledge: And no one but the unjust reject Our Signs." Koran 64:8 cautions, "Therefore, believe in Allah and His Messenger, and in the Light that We have sent down."

41. Peters, supra note 34, at 121.

42. Moojan Momen, An Introduction to Shi'i Islam 147 (1985).

43. Peters, supra note 34 , at 136.

44. Id.

45. Id. at 138 .

46. Id.

47. Momen, supra note 42, at 192. 
O you who believe! Obey Allah, and obey the Messenger (Muhammad), and those charged with authority among you. If you differ about anything within yourselves, refer it to Allah and His Prophet (Muhammad), if you believe in Allah and the Last Day: That is best and most suitable for final determination. ${ }^{48}$

According to Shi' ite doctrine, this verse asserts that neither the secular rulers nor the legal scholars were infallible or divine substitutes for the leadership of the Imam. ${ }^{49}$ In sum, "those in authority" referenced in the above verse are only those who have been divinely designated and infallible: the Imams. ${ }^{50}$

While any attempt to install a subordinate political figurehead in the Imam's absence would necessarily lack fundamental legitimacy, the question remained: in the absence of this spiritual leader, who would interpret Shari'a? In the absence of this political leader, who would rule over the Muslim community? And, ultimately, who would speak for Islam in the international community of the modern world?

Because Shi'ite theory developed during a time when Sunnis were the majority faction and occupied positions of power, the theory of the Hidden Imam was easily maintained; Shi'ites merely denied the legitimacy of the Sunni leadership as a usurpation of Imam power. ${ }^{51}$ A change in the political landscape quickly illuminated the inconvenience of this traditional Shi'ite theory. Today, the Shi'ite community has expanded and emerged as the majority population in a number of territories, including Iran,$^{52}$ once again raising the threshold question of the derivation of leadership authority.

\section{A. Islamic Authority and Leadership in Post-Revolutionary Iran}

When Khomeini assumed the supreme leadership position in Iran after a period of secular rule, he was faced with the theoretical conundrum just discussed. In order to justify his leadership position, Khomeini employed the concept

48. Koran 4:59.

49. Said Amir Arjomand, The Turban for the Crown: The Islamic Revolution in Iran 177 (1988).

50. Momen, supra note 42, at 192.

51. Neil Shevlin, Comment, Velayat-E Faqih in the Constitution of Iran: The Implementation of Theocracy, 1 U. PA. J. Const. L. 358, 359 (1998).

52. Roy, supra note 14, at 168 (stating that "Iran is the only country in which Shiism is the state religion"). 
of vilayat-i faqih, the guardianship of Islamic jurist, ${ }^{53}$ a concept that had long been debated, but was only elevated to practice upon Khomeini's rise to power. ${ }^{54}$ The theory, as Khomeini preached prior to taking office, stands for the proposition that there is no distinction between government and religion in Islam. ${ }^{55}$ This general definition comports with the traditional Islamic idea that church and state are indivisible, but, in its application, has resulted in what appears to be an un-Islamic elevation of the state over the Shari'a. ${ }^{56}$ This deviation occurred largely because, like many theories, vilayat-i faqih is not easily applied.

The collection of taxes is particularly illustrative of the difficulty of applying vilayat-i faqih. In his initial invocation of vilayat-i faqih during the infant stages of implanting a "one hundred percent Islamic" constitution, Khomeini taxed Iranians only to the extent needed to care for the poor. ${ }^{58}$ In doing so, Khomeini made good on his promise to apply Shari'a law, as this was the exact financial system taught by the Prophet. ${ }^{59}$ Like the Prophet, Khomeini relied upon donations for the monies needed to prop up the state. ${ }^{60}$ In a decision that seems convenient rather than pious, Khomeini reversed his stance and levied additional taxes when it became apparent that such a system could not sustain itself.61 Of course, it is impossible to accurately deduce Khomeini's actual intentions, but the correlation between the tax policy's infeasibility and subsequent modification is hard to ignore.

By invoking and modifying this concept as practicality required, Khomeini glossed over the traditional texts' distaste for political state action. In addition, the Iranian Constitution codified several practices that appear primarily political in scope, such as the creation of the President as the highest state authority. ${ }^{62}$ This expansion of power from the religious leader to the head of state, seemingly parallel to Western political structures, was vehemently questioned by senior clerics who

53. Id. at 173.

54. Robert Gleave, Velayat-e Faqih, in Encyclopedia of IsLa m and THE Muslim World 722, 722 (Richard C. Martin ed., 2004).

55. Shevlin, supra note 51, at 365.

56. Roy, supra note 14 , at 179.

57. Shevlin, supra note 51, at 369 (quoting Shaul Bakhash, The Reign of the Ayatollahs: Iran and the Islamic Revolution 81 (1984)).

58. Id. at 372; Koran 9:60 ("Alms (goods and money given in charity) are for the poor and the needy.").

59. Koran 9:60.

60. Shevlin, supra note 51 , at 372.

61. Id. at 373 .

62. Id. at $367-68$. 
thought such action was an un-Islamic usurpation of Imam power. ${ }^{63}$ These disapproving clerics held fast to the idea that while scholars had maintained interpretative powers in the absence of the Imam, that authority was not to be expanded to the political sphere of Islam, regardless of the surrounding political landscape. ${ }^{64}$ The schism that occurred between Khomeini and the clerics, and the concessions that Khomeini was forced to make in the face of practical considerations, illustrates the idea that political considerations have trumped traditional Islamic doctrine. The trouble Khomeini faced when trying to implement traditional Islamic ideals further indicates that a return to strict, traditional Islamic law was, even then, no longer a viable option. Khomeini spoke of reliance on traditional Islam while his actions conveyed a rational concern for political expediency.

The Iranian Constitution itself provides additional examples of the way in which Khomeini led Iran away from traditional Islamic law. Article $56^{65}$ has been used by the Iranian Majles, or Parliament, to provide legislative authority seemingly in direct conflict with the spirit of divine sovereignty. ${ }^{66}$ Additionally, Khomeini explicitly endorsed violating Islamic law in a proclamation released on January 7, 1989, in which he stated, "[t] he government is empowered to unilaterally revoke any sharia agreements which it has concluded with the people when those agreements are contrary to the interest of the country or to Islam." ${ }^{77}$ Because a Shari'a agreement, by definition, is in compliance with Shari'a law, his reference to an agreement that is "contrary to Islam" may best be read as a pseudonym for "contrary to the state." The principle of state self-interest has long been a political reality in secular states, but does not coincide with the primacy of Shari'a in an Islamic Republic. Khomeini's edict effectively declared that executive absolutism has replaced traditional Imam supremacy. With his statement, Khomeini grossly undermined historical notions of traditional Shi' ${ }^{\prime} \mathrm{sm}^{68}$ and in doing so, aligned his

63. See Ann Elizabeth Mayer, Islam and the State, 12 CArdozo L. Rev. 1015, 1039 (1991); Tamadonfar, supra note 2, at 214.

64. A RJomord, supra note 49 , at 180.

65. "Absolute sovereignty over the world and man belongs to God, and it is $\mathrm{He}$ Who has made man master of his own social destiny. No one can deprive man of this divine right, nor subordinate it to the vested interests of a particular individual or group. The people are to exercise this divine right in the manner specified in the following articles." Qanuni Assassi Jumhuri'I Isla'mai Iran [The Constitution of the Islamic Republic of Iran] 1358 [1980] art. 56.

66. Mayer, supra note 63, at 1037.

67. S. Sayyid, A Fundamental Fear: Eurocentrism and the Emergence of Islamism 12 (2d ed. 2003).

68. See Qanuni Assassi Jumhuri'I Isla'mai Iran [The Constitution of the Islamic Republic of Iran] $1358[1980]$ art. 4. 
political actions, and those of his government, with the secular nations worldwide rather than the legal principles of traditional Islam.

Following Khomeini's rule, the qualifications for the supreme religious leader originally set out in Articles 5, 107, and 109 of the Iranian Constitution had to be lowered so that Sayyid Ali Khamene'i could qualify to succeed as the new leader of Iran. ${ }^{69}$ When the Constitution was enacted, Khomeini proclaimed that it was "one hundred percent Islamic," yet these provisions were revised just a short time later and redefined who was qualified to lead an Islamic Republic. Because Khamene' $i$ was not an Ayatollah and not sufficiently knowledgeable in Islamic jurisprudence, his appointment lends credence to the argument that leadership in Iran has strayed, for political reasons, not only from the divine and thus legitimate authority of the Imams, but also from the delegated authority of those properly trained in Sharia law. In a striking departure from traditional Islamic law, the leadership position in Iran has become more congruent with the political head of state status of secular countries, those who are active on the world stage as self-interested leaders, not religiously trained clerics capable of deciphering God's will.

\section{International Relations in Islam: The Siyar}

The earliest ideas of Islamic international law may not have envisioned the formal organization of bodies like the United Nations; nonetheless, an early theory of international relations was adopted. Because the goal of universality did not come to fruition as expected, international relations became an inescapable reality forcing scholars to attempt to reconcile such action with the traditional sources of Islamic law. In doing so, jurists and scholars developed the theory of Islamic international law, the siyar. Abu Hanifah is known as the first to coin this term during his lectures on Muslim laws of war and peace. ${ }^{70}$ Siyar is not a source of Islamic law but is rather a compilation of the traditional sources of Shari'a.

Like all aspects of Islamic law, the siyar is thought to be based on Koranic revelations and prophetic traditions-specifically, in the realm of conducting war and relations with states. ${ }^{71}$ Since it was expected that the Islamic empire would continue to spread and convert the harbis (people of the territory of war) ${ }^{72}$ to Islam,

69. Shevlin, supra note 51 , at 377,378 .

70. Munammad Hamidullah, The Muslim Conduct of State 10-11 (1953).

71. Anke Iman Bouzenita, The Siyar-An Islamic Law of Nations?, 35 Asıan J. Soc. Sci. 19, 20-21 (2007).

72. Khadduri, supra note 13 , at 359 . 
siyar was thought to be a temporary institution. ${ }^{73}$ If there was but one state of Islam, in theory, there would be no need for international relations. Authority and rule would be conducted internally within the universal state of Islam. The perpetual existence of individual states, however, continues the relevance of the siyar in modern Islamic law. The siyar must then find its authority from the traditional sources of Shari'a.

The primary compilation of siyar was produced by the jurist and Hanafi student, Muhammad ibn al-Hasan al-Shaybani. ${ }^{74}$ The siyar continues the theme of non-recognition of non-Muslim states and the separation of the world into two distinct and perpetually feuding spheres of believers and nonbelievers. ${ }^{75}$ Shaybani's Siyar has long been thought to hold considerable authority largely because of his proximity to the Prophet. ${ }^{76}$ The scholar died in $804 \mathrm{CE}$, and his compilation remains influential in the debate over Islamic international law. ${ }^{77}$

Because the siyar was developed as a result of the continued existence of the dar al-harb, Islamic international law and Shaybani's collection are predominantly concerned with the laws of war. This focus on the conduct of war compliments the idea that the Islamic state was an "imperial and expansionist state striving to win other people by conversion." ${ }^{\prime 7}$ In the fifth chapter of Shaybani's compilation, he discusses the ability of Muslims to enter into treaties when Islamic territory has been invaded by a non-Muslim enemy. ${ }^{79}$ According to the siyar, if the Imam determines that the nonbelievers are stronger than the Muslims, it would be better to make peace with them than to risk destruction. The Imam continued to specify that the peace should be for a limited duration. ${ }^{80}$

The siyar's authorization to temporarily capitulate in the face of defeat specifically addresses the possibility that Muslim countries have joined the international community and are abiding by their treaties precisely because of the current power differential between Islam and the West. What this means for modern, public international law is unclear. However, based on the siyar, it is clear that any traditional authority a Muslim leader may possess to enter into international agreements is not without reservation.

73. Id.

74. KHAdDURI, supra note 6 , at 41.

75. Id. at 11 .

76. Id. at $24-26$.

77. Id. at 22.

78. Id. at 5 .

79. Id. at 155 .

80. Id. 


\section{Justifications OfFered for Entering into International Agreements}

The Islamic conception of the state presented in Part I does not easily lend itself to a modern day international framework built on agreements of peace and mutual alliances. In AbuSulayman's study, he refers to this as the space-time problem of Islamic politics. ${ }^{81}$ AbuSulayman's contention directly addresses the problem Islam faces when confronted with a byproduct of globalization, the international agreement. Traditional notions of Islam cannot hold in the current global political climate. According to AbuSulayman's theory of the space-time problem, inquiries into the "Islamicity" of a treaty lasting more than ten years or the permissibility of negotiating with non-Muslim countries are of limited utility and relevance and should be viewed accordingly in the limited context of $\mathrm{Mu}$ hammadian times. ${ }^{82}$ While his recognition of the problem is pointed and accurate, AbuSulayman's recommendation for Islamic adaptation in order to harmonize with the modern world order is overly simplistic and offers little justification rooted in Islamic law. AbuSalayman is just one example of an Islamic scholar who advocates for this revisionist style of Islam in a way that looks unapologetically defeatist-applying Islamic international relations as a theory based on something as fleeting as historical contingency.

Some scholars have tackled the space-time problem by invoking the twostaged revelation of the Koran, that of the Medinan and Meccan periods. ${ }^{83}$ Those who argue that Islam can adapt to changing conditions claim that the two periods of revelation represent different political environments and accordingly prescribe different behavior for the Islamic community. The argument is extended to conclude that today's global conditions can be met by a similar adjustment. This method of jurisprudence, however, appears to allow society to shape the law, a secular proposition, rather than to adhere to the Islamic concept that the law should shape society. ${ }^{84}$ In addition, merely allowing Western or outside political circumstances to determine the trajectory of Islamic international relations indicates that despite claims to the contrary, Islam is looking outside the Shari'a. Traditional Islam of modern day is in a paradoxical and arguably untenable position:

81. A buSulayman, supra note 25 , at 58.

82. Id. at $129-33,140$.

83. Ford, supra note 27 , at 513 .

84. The idea that in Islam law must not be shaped by society can be seen in Coulson, supra note 30 , at 2 ("There can thus be no notion of the law itself evolving as an historical phenomenon closely tied with the progress of society."). 
traditional Islam demands that society be bound to Shari'a and participation on the global scale requires adherence to agreements crafted apart from Sharia.

While the West may currently have control of the international community, Sura 4 of the Koran contains the explicit decree that "never will Allah grant to the

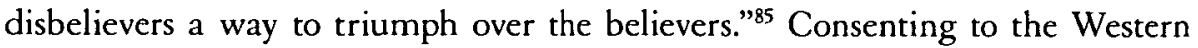
style of international relations by adjusting traditional Islamic theory seems to concede the triumph of the disbelievers, directly conflicting with the Koran. Additionally, while the two-staged revelation provides a theoretical answer to the current geopolitical landscape, it can be argued that this convenient answer is, in reality, a compulsory appeasement model of Islam. If that is indeed the case, the absoluteness of the revelation is undermined by permitting its meaning to undergo constant alteration, and, yet there may be no viable alternative.

Statements by the Islamic legal scholar Majid Khadduri, support the proposition that Muslim countries will continue to integrate into the international community in order to represent Islam on the world stage, insinuating that political relevance, not adherence to Islam, is the ultimate goal of an Islamic Republic. The interconnectedness of the post-World War II era has forced this distinction and has also forced this choice upon Islamic leaders. This is close to a historical definition of pragmatic diplomacy. The welfare of the state, rather than traditional sources of Islamic law, provides the justification for the expansion of Islamic international relations.

In searching for law to govern international relations, jurists have looked to the primary source of Islamic law-the Koran. The word siyat, meaning "motion" or "travel" is found in several Koran verses. The plural form, however, siyar, which has come to mean "conduct of the ruler," is not explicitly set out in the Koran. ${ }^{86}$ Therefore, it can be argued that the primary source of Islamic law does not give impetus to a theory of Islamic international law. Additionally, the Koran does not explicitly call for, nor define, any specific set of legal rules regarding relations between states, contributing to the difficulty in resolving the theoretical problems that arise when a state attempts to harmonize traditional Shari'a law with modern geopolitics.

85. Koran 4:141 reads: "(The hypocrites are) the ones who sit and watch about you: If you do gain a victory from Allah, they say: 'Were we not with you?' But if the disbelievers gain a success, they say (to them): 'Did we not gain an advantage over you, and did we not guard you from the believers?' But Allah will judge between you on the Day of Judgment. And never will Allah grant to the disbelievers a way to win over the believers."

86. Bouzenita, supra note 71 , at 20 . 


\section{A. Pacta Sunt Servanda: Muslim Pledge to Stay True to Promises Made}

The argument has been made that the Koran provides adequate justification for entering into international agreements through its requirement that Muslims respect and stay true to their promises. ${ }^{87}$ Several verses within the Koran speak to this general command.$^{88}$ This reverence for one's word is referred to as the principle of pacta sunt servanda, and while it does not specifically refer to international obligations, it has been analogously applied. ${ }^{89}$ The principle instructs Muslims that they must never be the first to denounce a contract and stems from the Koranic command, "O you who believe! Fulfill (all your) obligations . .."90 This passage is the basis for the Arab saying, Al-Aqd Shariat Al-Muta'aqdin, "the contract is the Sharia of the parties." Because the passage does not specify nor distinguish any particular pact or contract to which this command applies, one can argue for its extension to the international agreements of today. ${ }^{92}$ As the author Hans Kruse noted in his study of an Islamic law of nations, this respect "'silently' presupposes an international standard with validity for believers and disbelievers ordering 'the loyalty to the given word."'93

Despite Kruse's assertion, this principle does not conclusively establish a theory of Islamic global relations. Pacta sunt servanda expresses a certain respect for a Muslim's word in contracting with outside parties; it, however, appears to be a logical misstep to conclude that such a level of respect for promises necessarily implies the initial political authority to enter into all forms of promises, including global agreements. The Koran offers the statement in Sura 9, "Allah loves the righteous," prevailing reason why Muslims must uphold their agreements. Righteousness is thus implicitly defined as one who remains true to his word. This circular logic of-

87. Ford, supra note 27 , at $518-19$.

88. See Koran $5: 1$; see also id. 8:55; 8:56; 17:34.

89. Ford, supra note 27, at 518 .

90. Koran 5:1.

91. Saba Habachy, Property, Right, and Contract in Muslim Law, 62 Colum. L. Rev. 450, 468 (1962); see also Koran 8:55-56 ("Verily, in the sight of Allah, the worst animals are those who reject Him: (And) they will not believe. They (the disbelievers) are those with whom you made a promise, but they break their promise every time, and they do not have the fear (of Allah).").

92. Ford, supra note 27, at 518 (discussing the Saudi Arabia and the Arabian-American Oil Company arbitration where it was stated, "[A]ny valid contract is obligatory, in accordance with the principles of Islam and the Law of God, as expressed in the Koran: 'Be faithful to your pledge to God, when you enter into a pact."')

93. Bouzenita, supra note 71, at 3 (quoting Hans Kruse, Islamische Völkerrchtslehre 130 (1979) (doctoral dissertation, Göttigen University)).

94. Koran 9:4. 
fers nothing to support the contention that Islamic heads of state possess the authoriry to operate as global players and to enter into such global agreements.

\section{B. Prophetic Traditions}

Continuing down the hierarchy of traditional sources of Islamic law, the jurists and scholars look to prophetic tradition to justify engaging in international relations. The Sunna is considered a source of Islamic law, second only to the Koran, for it is a compilation of Mohammad's sayings and doings and is intended to serve as an example to future generations of pious Muslims. ${ }^{95}$ As the human representative of God, the Prophet provided divine instruction to the Muslim community. Muslim traditions and commentary are validated by their proximity to the Prophet, most often through a chain of transmission analyzing and authenticating each subsequent narrator.

The Hudaybiya Treaty, negotiated between Mohammad and the Meccans in the year $628 \mathrm{CE}$, was the first treaty in Islam and has been touted as an exemplary authoritative source and precedent for international agreements between Muslims and non-Muslims. ${ }^{96}$ The argument can be made that Mohammad's willingness to enter into an agreement with non-Muslims is an example of the correct way to live by God's law, and therefore, grants Muslims permission to enter into future, global negotiations as modern times require. This original treaty negotiated an end to the fighting between the two sects and called for a ten-year peace agreement. ${ }^{97}$ Upon a minor, technical breach by the Meccans, however, Mohammad repudiated the treaty and attacked Mecca only three years after the agreement was signed. The attack led to Muslim infiltration and conquest of the entire Meccan region..$^{98}$ While some scholars hold fast to the belief that the peace was void as a result of the breach, the implication is striking that the treaty and subsequent attack served to further the global spread of the religion, and all other international agreements yield to this primary goal.

It is from the failed Hudaybiya Treaty that some Islamic leaders and scholars

95. Coulson supra note 30, at 42, 55-57.

96. See generally Daniel Pipes, Lessons From the Prophet Muhammad's Diplomacy, MiddeE E. Q., Sept. 1999, http://www.meforum.org/480/lessons-from-the-prophet-muhammads-diplomacy.

97. Id. (quoting the text of the treaty: "the two sides 'agreed to remove war from the people for ten years. During this time the people are to be security and no one is to lay hands on another. . . Between us no evil is to be abstained from, and there is to be no raiding or spoliation."'), translated from W. Montgomery Watt, Muhammad at Medina 47-48 (1956).

98. Pipes, supra note 96. 
argue prophetic tradition provides proof that the head of an Islamic state wields the authority and power to enter into global agreements of limited duration. ${ }^{99}$ Some jurists argue that the duration must be no longer than ten years, ${ }^{100}$ while the Hanafi and Maliki schools of Sunni jurisprudence maintain that three years is the accurate period of a treaty's validity. ${ }^{101}$ While there is disagreement over the precise length, clearly the principle of non-recognition, as represented by some form of durational limitation, remains. In addition to durational considerations, scholars have analyzed and debated other aspects of the Hudaybiya Treaty's precedential value and its implications for modern international negotiations. ${ }^{102}$ It has been suggested that Mohammad agreed to the concessions for peace because his troops were weak and could not sustain an attack at the time. ${ }^{103}$ Following a build-up of military allies and an increase in strength, Mohammad used the minor breach as the casus belli for the conquest of Mecca. ${ }^{104}$

From an insider's perspective, this tradition of the Prophet provides for the adherence to promises and international agreements as long as the opposing signatories remain in strict compliance with the terms of the agreement. In contrast, to outsiders interested in the binding effect of international agreements in Islam, the Hudaybiya Treaty provides authority on two grounds: one, that treaties with Muslim nations are finite; and two, that Muslim leaders will make concessions when militarily necessary but only until it becomes politically expedient and physically possible for them to break from these obligations. Implicit in this reading of the tradition is that the goal of Pax Islamica trumps international cooperation.

The competing interpretations of the Hudaybiya Treaty precedent leave many uncertainties for international relations with Muslim countries. While there are many scholars and leaders who disagree, the initial time limitation attached to the peace agreement, followed by its politically convenient dismantling, together seem to strongly suggest that if the leader of a Muslim country has the authority to enter into international agreements, it is only valid when the agreements are politically advantageous for Muslims. Additionally, if it later becomes clear that a

99. See generally Perry Smith, Of War and Peace: The Hudaibiya Model of Islamic Diplomacy, 18. FLA. J. INT'L L. 135, 154 (2005) (arguing that the historical treaties of Islam can be analogized to current international law).

100. Id. at 151 .

101. Id.

102. See Pipes, supra note 96 (quoting several Western historians whom all question the diplomatic principles arising from Hudaybiya).

103. Id.

104. Id. 
previously agreed-upon treaty is a hindrance to Islam, the leader should use any small infraction to abandon his commitments if doing so would benefit the Muslim community. This view is shared by some Western political figures and is certain to color future negotiations with countries that claim to govern based on traditional Shari'a law, even when it appears they are adhering to a doctrine of political expediency rather than religious textual compliance. ${ }^{105}$

\section{Conclusion}

International law and corresponding agreements are premised upon the idea that in order to live in peace and to establish a sustainable political world order the international system must respect and accommodate different belief systems. The preeminent treaties of our time exist not to reconcile religious or cultural beliefs across borders, but rather to ensure that such divergent ideologies can coexist in an environment fostering stability-a globalization of tolerance for the greater good. This concept of "order without shared belief," 106 encompassed within international agreements, is not available without the bifurcation of religion and law in Islam. Islamic leadership must be able to commit to international agreements that have no basis in traditional Islamic law. In its dealings with a state like Iran, the international community does not have the ability to contract with the legal head of the Islamic community while ignoring the community's religious counterpart. In contrast to a nation that derives political authority from popular sovereignty, an Islamic government that operates under the banner of traditional Islam cannot legally agree to an non-Islamic treaty for the sake of order or peace; the freedom to make such a political calculation is absent. If every aspect of a Muslim's life must be congruent with Islamic law and justified within religious text, international cooperation must not take precedence over God's will. In recognizing this truism, the potential tension between international agreements and Islamic law becomes immediately apparent.

The cross-border nature of modern politics has illuminated the draconian nature of the dar al-Islam and dar al-harb distinction, and the religion of Islam has adjusted accordingly. The political cost of maintaining a system of perpetual hostility is

105. See, for example, Representative Jim Saxton's statement asking "how can anyone trust an agreement compared to the Treaty of Hudaibiya enacted by the Prophet Muhammad, in which a treaty lasts as long as political expediency dictates?" Abdul Hadi Palazzi, The Truth About the Treaty of Hudaybiyyah, Aug. 29, 1999, http://www.rb.org.il/RBIS/RBIS\%201999/RBIS\%201999.08.29.htm.

106. Westbrook, supra note 9 , at 829. 
too high for the modern state, including an Islamic Republic. Organizations, such as the United Nations, exist to nullify as much as possible the constant threat of war and replace it with a sophisticated system of mutual cooperation and agreement across international borders. As the result of necessity and a desire for relevancy, Muslim countries have opted to participate in the current system. A reversal of course is unlikely, despite rallying calls for a reversion to traditional Islam in states like Iran.

This participation and assimilation may be temporary as a result of the power differential between Muslim and non-Muslim states, but does traditional Islam allow for such concession of subjugation? Certainly the Koran does not explicitly authorize this, but can such a concept be extrapolated? As previously noted, the concept of siyar provides some support for this proposition. With a nuclear, nonIslamic power occupying a hegemonic position of world dominance, the alternative could result in the annihilation of Islam. Thus, the emergence of complex international relations and the decline of Muslim world power may require that the traditional questions of Islamic international relations, like duration and recognition limitations, be replaced by a more general concern for the continued existence of Islam. This shift in priorities, from the spread of Islam to its mere survival, suggests that political Islam has deviated from the traditional Islamic legal sources as a result of external circumstances. Unless the power structure between the West and Islam reverses course, Iran and other nations will not succeed in their stated quest to return to Shari'a Islamic law.

Upon looking to the hadiths and traditions of Mohammad, an Islamic state may find some authorization to contract with international bodies, but the exact requirements and limitations are unclear. What is clear is that Muslim countries have long been entering into international agreements, and there is no indication that this will change in the name of restoration to traditional Islam. Rather, leaders will continue to justify such behavior because abstaining from participating in the world community and international affairs is not a viable option. In sum, states that proclaim to be governed by strict application of Shari'a are operating under a revisionist notion of traditional Islam, a concept that is, in essence, an oxymoron. 


\section{Indiana University Press/Journals}
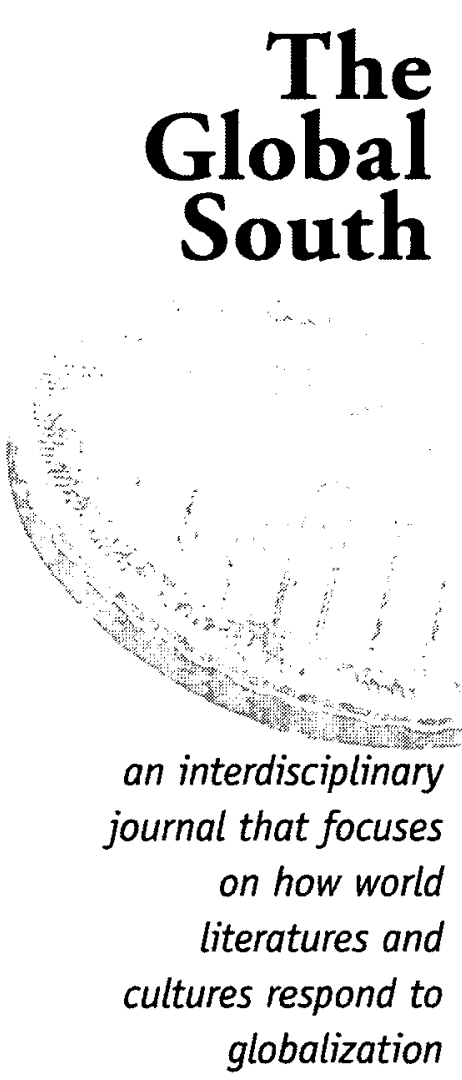

PUBLISHED SEMIANNUALLY EISSN 1932-8656 pISSN 1932-8648

800-842-6796/812-855-8817

http://inscribe.iupress.org Available in electronic, combined electronic \& print, and print formats

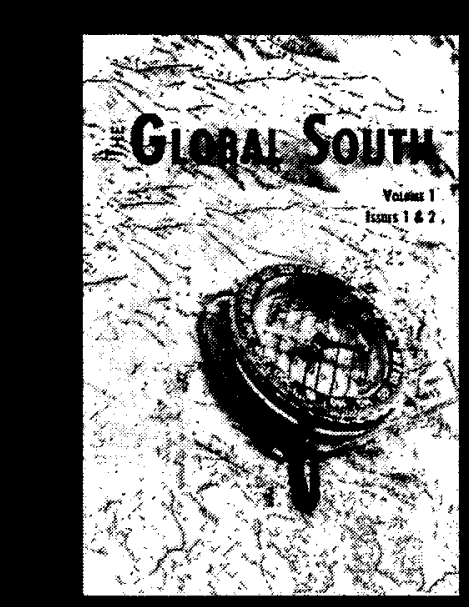

EDITED BY ADETAYO ALABI

The Global South is an

interdisciplinary journal that focuses on how world literatures and cultures respond to globalization, particularly how authors, writers, and critics respond to issues of the environment, poverty, immigration, gender, race, hybridity, cultural formation and transformation, colonialism and postcolonialism, modernity and postmodernity, transatlantic encounters, homes, and diasporas, and resistance and counter discourse, among other issues, under the superordinate umbrella of globalization.

\section{INDIANA UNIVERSITY PRESS}

601 North Morton Street, Bloomington, Indiana 47404-3797 USA 